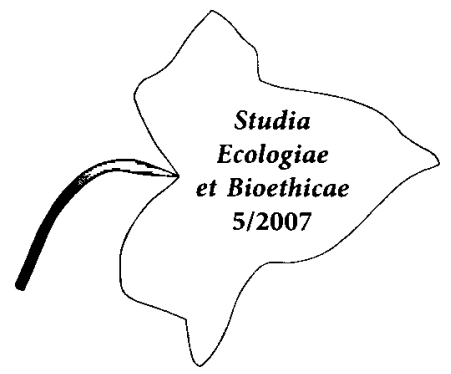

\title{
Wykorzystanie ochrony środowiska w działalności promocyjnej, informacyjnej, administracyjnej na podstawie badań przeprowadzonych w Gminie Świętajno
}

\section{Słowo wstępne}

Ochrona środowiska jest jedną z tych dziedzin działalności człowieka, która poza jej podstawowym celem spełnia też wiele innych, nie mniej ważnych funkcji. Umiejętne wykorzystanie działań pro-ekologicznych jest bardzo skuteczną metodą na pobudzenie różnych, pozornie nie związanych ze sobą gałęzi gospodarki. Liczne przykłady udanych kampanii reklamowych wykorzystujących jako motyw przewodni dbałość o środowisko naturalne dowodzą tego, iż nawet produkcję hutniczą można reklamować jako „czystą” ekologicznie, a efekty takich działań bezpośrednio się przekładają na wysokie korzyści finansowe.

Polska, jako kraj o stosunkowo młodej gospodarce wolnorynkowej wciąż uczy się jak wykorzystywać potencjał jaki posiada. Wiele atutów nadal pozostaje nie wykorzystanych. Podział kraju na część uprzemysłowioną, zurbanizowaną oraz na część rolniczą, wolną od ciężkiego przemysłu przez wiele lata krytykowany był ze względu na nierówności jakie się wytworzyły w wielu dziedzinach, począwszy od stopy bezrobocia i poziomu $\mathrm{PKB}$ na pojedynczego mieszkańca po infrastrukturę drogową i kolejową. Dziś jest szansa zniwelować powstałe rozbieżności wykorzystując fakt, iż część Polski, w której zaniedbano rozwój przemysłu i urbanizacji dzięki temu zachowała swój największy skarb jakim jest nienaruszone środowisko naturalne.

Unia Europejska jest wspólnotą państw mającą na celu realizowanie wspólnych celów ekonomiczno-społecznych. W ramach tej wspólnoty powołano wiele instytucji zajmujących się szczegółowo określonymi dziedzinami współpracy miedzy krajami wewnątrz Unii. Polączenie się wielu rynków ekonomicznych sprawiło, że wzrosła konkurencja pomiędzy reprezentantami poszczególnych krajów a każdy $z$ nich stara się przedstawić jak najwięcej swoich atutów by po- 
tencjalny odbiorca wybrał jego produkt a nie inny. Podobnie ma się sprawa w dziedzinie ochrony środowiska. Działalność ta, wydawać by się mogło „non profit” jest w rzeczywistości działalnością bardzo dochodową, lecz jej sukces jest bardzo ściśle powiązany z marketingiem i public relations. Zależność tą doskonale wykorzystują do promowania walorów swojego regionu np. kraje śródziemnomorskie, które mimo bardzo rozwiniętego przemysłu ciężkiego stworzyły wizerunek krajów, a w każdym z nich poszczególnych regionów, w których dbałość o środowisko naturalne jest priorytetem a dzięki temu przyciągają do siebie setki tysięcy turystów z całego świata. Polska, mimo faktu, że w strukturze unijnej jest już kilka lat nieudolnie wykorzystuje swój wielki atut jakim jest stosunkowo mało zdegradowane środowisko naturalne. Polski przemysł ciężki jest skupiony w kilku dużych ośrodkach, a większość kraju jest od niego wolna. Dlaczego by nie wykorzystać szansy wypromowania Polski jako kraju w którym dba się o środowisko naturalne, kraju wolnego od zanieczyszczeń przemysłowych w którym można odpocząć i poznawać ostatnie w Europie pradawne kompleksy lasów i jezior?

\section{O regionie}

Istnieją w Polsce regiony, w których dostrzega się szansę, jaką stanowi promocja oparta na ochronie środowiska. Jednym $z$ takich regionów jest Gmina Świętajno znajdująca się w północno-wschodniej części województwa warmińsko-mazurskiego.

Gmina Świętajno „jest terenem typowo rolniczym, o wspaniałych walorach przyrodniczych. Stolicą gminy jest Świętajno, które stanowi ważny ośrodek życia społecznego i kulturalnego mieszkańców. Tutaj mieści się siedziba władz samorządowych i innych instytucji potrzebnych do funkcjonowania społeczności lokalnej (Bank Spółdzielczy, Ośrodek Zdrowia, Lecznica dla zwierząt, Urząd Pocztowy, Posterunek Policji, Posterunek Energetyczny oraz Gminny Ośrodek Kultury z Gminną Biblioteką Publiczną). Na terenie gminy funkcjonuje 5 szkół podstawowych"'.

„Świętajno jest największą miejscowością w gminie (1083 mieszkańców co stanowi $25 \%$ populacji gminy), a tym samym ośrodkiem administracyjnym, leżącym przy drodze powiatowej nr P-424, łączącej się z drogą wojewódzką OleckoGiżycko nr. W-655. Odległość od powiatu oleckiego wynosi $16 \mathrm{~km}$, a do najbliższych miast: Ełk - 28km i Giżycko - 45 km"2.

\footnotetext{
Powiat Olecki, s. 19.

2 Studium Uwarunkowań i Kierunków Zagospodarowania Przestrzennego Gminy Świętajno, BDK, Olsztyn 2000, s. 7.
} 
Gmina Świętajno jest typową gminą wiejską, na terenie której znajduje się 21 sołectw, 30 wsi które łącznie zamieszkuje 4346 mieszkańców, co daje średnią gęstość zaludnienia 20 osób na $\mathrm{km}^{2}$. Powierzchnia gminy to $2149 \mathrm{lha}$, z czego 1054ha zajmują wody. Większość mieszkańców gminy zajmuje się rolnictwem lub gospodarką leśną, a z całej powierzchni gminy 11879 ha stanowią użytki rolne. Niewielkie zakłady przemysłowe zajmują się przetwórstwem produktów rolnych i drewna.

\section{Rys historyczny}

Najstarsze świadectwa pobytu ludzi na terenie wschodnich Mazur pochodzą z okresu paleolitu, czyli co najmniej 10 tys. lat p.n.e. Ważny okres w dziejach tej prehistorycznej krainy przypada na połowę pierwszego tysiąclecia p.n.e., kiedy przybyły tu z dorzecza Dniepru grupy ludności utożsamiane etnicznie z Bałtami. W początkowej fazie tzw. okresu rzymskiego (I-XI w. n.e.) osadnictwo battyjskie koncentrowało się także w okolicy Wielkich Jezior. W okresie wczesnego średniowiecza nad jeziorem Świętajno zamieszkiwali Jaćwingowie, którzy opuścili te tereny pod koniec XIII w. wyniku podboju zakonu krzyżackiego. Jaćwingowie nie zdotali wytworzyć jednolitej organizacji państwowej, stanowili zespół luźnych włości, jedna z nich - Świętajny (Sentane) położona była w okolicy jeziora Świętajno i to prawdopodobnie od niej wywodzi się dzisiejsza nazwa wsi. Przeniesiona została z nazwy jeziora, której słowiański rdzeń „swet”-,święty” Prusowie przejęli w znaczeniu „błyszczący”, formant „-ajno” miałby powstać pod wpływem litewskim $z$ dyftongu "-ai”. Miejscowość ta nosiła także w przeszłości inną nazwę, oboczną „Kowale”. Wywodzi się ona od Szczepana Kowala, który na mocy przywileju lokacyjnego starosty książęcego - Krzysztofa Glaubnitza - założył nad jeziorem Świętajno 16 marca 1554 roku wieś czynszową. W tym celu otrzymał on 4 włóki sołeckie, a na dalszych 40 włókach zobowiązał się osadzić chłopów, którzy mieli zagospodarować opustoszałą od dwóch stuleci ziemię. W pierwszych wiekach swojej historii w Świętajnie mieszkali sami Polacy, o czym świadczy fakt, że jeszcze w latach 1806-1820 w szkołach parafii nie było ani jednego dziecka narodowości niemieckiej. W XIX wieku i początkach XX Świętajno rozrosło się do jednej z największych osad na ziemi Oleckiej. Posiadało m.in. Urząd Stanu Cywilnego, Pocztę, Okręgowy Urząd Arbitrażowy, punkty badania mięsa, posterunek żandarmerii, wyżej zorganizowaną, trzyklasową szkołę powszechną, a od 1911 roku także stację kolejki wąskotorowej Świętajno-Olecko-Garbas. Czynne były we wsi liczne zakłady rzemieślnicze i usługowe. W 1938 roku Świętajno liczyło 761 mieszkańców. $\mathrm{W}$ różnych okresach jego historii związane były z nim takie folwarki i dwory, jak Grądy, Rogowszczyzna, Luinsenhof i inne, które w wyniku parcelacji, podziałów rodzinnych i reform agrarnych odłączyły się od macierzystej wsi. 


\section{Przyroda gminy Świętajno}

Gmina Świętajno, jak całe Mazury, leży na terenie ukształtowanym przez ostatnią epokę lodowcową. Najwyższe wzniesienia tworzą wzgórza moren czołowych: akumulacyjnych i spiętrzonych, występujących w zachodniej i północno-wschodniej jej części. Kumulacje wzgórz na zachodzie sięgają do 190 m n.p.m., a na północnym-wschodzie przekraczają $220 \mathrm{~m}$ n.p.m. przy wysokości względnej od 20 do $30 \mathrm{~m}$. Środkowa część gminy tworzy tzw. strefę rozcięcia marginalnego. Wzgórza morenowe tworzą wyraźne ciągi, towarzyszy im pagórkowata wysoczyzna polodowcowa strefy marginalnej o dużych deniwelacjach - od 15 do $20 \mathrm{~m}$, stromych pagórków, licznych obniżeniach wytopiskowych oraz głębokich rynnach polodowcowych. Poza sferą marginalną wysoczyzna polodowcowa, która sięga tu wysokości 140-165m n.p.m. a deniwelacje dochodzą do $15 \mathrm{~m}$., porozcinana jest siecią równoległych rynien wypełnionych przez jeziora lub sandry. Charakterystyczne dla tego terenu formy to wzgórza kemowe i moreny martwego lodu o bardzo zróżnicowanej wielkości i kształcie. Najbardziej okazałe, o wysokości do $25 \mathrm{~m}$ i powierzchni do $1 \mathrm{~km}^{2}$ występują w południowej i wschodniej części gminy. Rynnom polodowcowym często towarzyszą wały ozów. Pomiędzy jeziorami Litygajno, Łaźno i Leśmiady rozwinęła się sieć odpływu sandrowego urozmaicona różnymi obniżeniami wytopiskowymi.

\section{Ochrona środowiska a rozwój Gminy}

Gmina Świętajno znajduje się na terenach posiadających niezwykłe walory przyrodnicze wchodzące w skład obszaru Zielonych Płuc Polski. Mnogość występującej tu fauny i flory świadczy o niskim poziomie degradacji środowiska naturalnego. Władze samorządowe dostrzegły potrzebę dbania o naturę poprzez systematyczne podnoszenie wydatków na ten cel. Najważniejsze zrealizowane inwestycje w tej dziedzinie to: oczyszczalnia ścieków w Świętajnie, kotłownia olejowa Szkoły Podstawowej, kanalizacja Świętajna i Sulejek. Kolejne inwestycje są na etapie planowania i początku realizacji.

Głównym założeniem władz samorządowych jest wykorzystanie walorów środowiska naturalnego oraz dbałości o ich zachowanie dla celów promocji regionu jako atrakcyjnego dla turystów. W tym celu zlecono przeprowadzenie licznych analiz i planów wykorzystania walorów przyrodniczych gminy.

Zasady ochrony środowiska na obszarze gminy oparto na istniejącym systemie ochrony prawnej, który rozszerzono o elementy wynikające $z$ prowadzonych niezależnie analiz środowiska przyrodniczego. W oparciu o nadrzędny (krajowy) system obszarów chronionych, stanowiący szkielet układu, oraz w oparciu o występujące cenne zasoby środowiska przyrodniczego na terenie gminy, na sys- 
tem gminy składają się: obszary węzłowe ( kompleksy leśne, jeziora, użytkowane tereny rolnicze z przewagą ląk i pastwisk uzupełnianych oczkami wodnymi, terenami podmokłymi i zadrzewionymi, obszary uzupełniające (obszary cenne przyrodniczo znajdujące się poza obszarami węzłowymi), korytarze ekologiczne (zachowanie możliwości migracji ptaków). „Na obszarach węzłowych i uzupełniających ustala się następujące ogólne zasady zagospodarowania terenu:

- preferuje się utrzymanie obecnego sposobu użytkowania terenu

- dopuszcza się zmiany użytkowania rolniczego na leśne na obszarach wyznaczonych granicą rolno-leśną

- dopuszcza się zmiany użytkowania rolniczego na turystyczne

- dopuszcza się tworzenie liniowych urządzeń infrastruktury rekreacyjnej wraz $\mathrm{z}$ ich niezbędnym zapleczem (punkty widokowe, miejsca piknikowe, deszczochrony, parkingi, itp.)

- korytarze ekologiczne stanowią przede wszystkim rzeki i cieki wodne wraz $\mathrm{z}$ terenami sąsiednimi o niskiej intensywności użytkowania (łąki, pastwiska, małe laski).

Na terenie korytarzy ekologicznych uważa się za konieczne utrzymanie biologicznej odbudowy cieków wodnych w postaci łąk, pastwisk, zadrzewień i zakrzewień. W wypadku gdy istnieje taka możliwość należy dążyć do zmiany użytkowania terenów w obszarze korytarzy ekologicznych na opisane powyżej. W ramach określonego powyżej systemu przyrodniczego ustanowiono ochronę prawną dla obszarów chronionego krajobrazu, stref ochronnych wokół wód, użytków ekologicznych i pomników przyrody. Postulowane jest objęcie ochroną Parku Krajobrazowego Puszczy Boreckiej (o projektowanej powierzchni 24003 ha), która swoim zasięgiem wchodzi na teren gminy. Wokół Parku wyznaczono otulinę, jako pas przejściowy o powierzchni 7404 ha"3.

Władze samorządowe dostrzegły też korzyści płynące z ochrony środowiska kulturowego. W tym celu przyjęły zasady opracowane pod kątem ochrony i kształtowania środowiska kulturowego gminy Świętajno. „Zakłada się rozszerzenie zakresu prawnego ochrony cennych elementów środowiska kulturowego poprzez wpisanie ich do rejestru zabytków. Dotyczy to zespołów dworskich i dworsko-parkowych w miejscowościach: Jurki, Chełchy, Jurkowo, Kukowo, Niemsty, Rogowszczyzna, Połom, Pietrasze oraz budynków szkolnych i leśniczówek. Ochroną należy objąć struktury osadnicze o zachowanym układzie przestrzennym i minimalnym stopniu deformacji krajobrazowej (Barany, Dybowo, Jelonek, Krzywe, Sulejki, Rogajny). Postuluje się o objęcie całego obszaru gminy strefą ochrony konserwatorskiej (SOK). Nie zakłada się wprowadzenia na terenie gminy wyższych organizacyjnie form ochrony konserwatorskiej, jak parki i re-

3 Studium... s. 20. 
zerwatu kulturowe. Specyfika krajobrazu kulturowego oraz wzmożone zainteresowanie inwestorów tym terenem zmusza do podjęcia działań elastycznych, które nie mogą jednak oznaczać ustępowania na rzecz gwałtownego przekształcenia antropologicznego. Wszelkie prace ziemne w obrębie udokumentowanych stanowisk archeologicznych, prace remontowe, modernizacyjne i rewaloryzacyjne obiektów zabytkowych wymagają zgody odnośnego organu służby konserwatorskiej. Teren gminy Świętajno należy do najlepiej przebadanych pod kątem rozpoznania zasobu stanowisk archeologicznych. Systematyczne badania rozpoznawcze (powierzchniowe) w ramach ogólnopolskiego programu badawczego objęły dotąd blisko $50 \%$ obszaru gminy"4.

Współczesny turysta jest wymagającym klientem, dla jego zwabienia nie wystarczą piękne lasy i jeziora ale niezbędna jest cała infrastruktura umożliwiająca wypoczynek i poznawanie danego regionu. W gminie Świętajno wciąż trwają prace nad rozwinięciem tej infrastruktury. Obecnie przez gminę przebiegają dwa oznakowane szlaki turystyki pieszej: z Rydzewa przez Krzywe, Połom, Wronki, Zalesie, Jelonek do Kruklanek oraz z gminy Ełk przez Leśniki, Kukowo, Dudko do Zabielna (gmina Olecko). Wędrując tymi szlakami turyści mogą zwiedzić pozostałości jaćwieskich osad,grodzisk i umocnień. F.J. Lubierzyński tak opisuje jedną $\mathrm{z}$ atrakcji turystyki pieszej: „Z Cichego idziemy szosą w kierunku południowym 2,5 km od wschodniego krańca wsi Dybowo; przechodzimy droga polną przez wieś i stąd zbaczamy w kierunku na Mazury. Po przejściu Dybowa około $300 \mathrm{~m}$ będziemy mieli po prawej stronie wzgórze między wąwozami. Jest to stary szaniec Jaćwingów. Po obejrzeniu go wracamy przez wieś do szosy i po przejściu $2 \mathrm{~km} \mathrm{w}$ kierunku południowym nie dochodząc do wsi Gryzy, polną drogą dojdziemy po kilometrowym marszu do znajdującej się między jeziorami Grodczyskim i Długim tzw. Zamkowej Góry, która na jednych mapach oznaczona jest jako Szaniec Szwedzki, na innych zaś jako grodzisko z epoki Jaćwingów. $Z$ góry tej roztacza się piękny widok na oba jeziora, malowniczy, wyżynny krajobraz"s.

Dla turystyki rowerowej, równie istotnej jak turystyka piesza, zostało przyjęte specjalne „Studium tras ścieżek rowerowych na obszarach województwa suwalskiego" opracowane przez Wojewódzkie Biuro Planowania Przestrzennego w Suwałkach w 1997 roku obejmujące swoim zasięgiem tereny gminy Świętajno. Dotyczy ono tras rowerowych o znaczeniu międzynarodowym i regionalnym mające charakter przelotowy. Uzupełnieniem tych tras jest propozycja utworzenia tras rowerowych o znaczeniu lokalnym. Większość szlaków wykorzystuje drogi o małym natężeniu ruchu oraz nieczynne nasypy kolejowe. Dla potrzeb tury-

Studium uwarunkowań... - kierunki rozwoju, s. 25.

F.J. LUBIERZYŃsKI, Ziemia olecka $z$ bliska i $z$ daleka, Białystok-Olecko 1970, s. 112. 
stów wyznaczono punkty węzłowe i miejsca postojowe w Świętajnie, Wronkach, Mazurach, wyposażone w urządzenia rekreacyjne i higieniczno-sanitarne oraz obsługi technicznej.

Dla turystyki wodnej wyznaczono dwa szlaki kajakowe: $z$ jeziora Łażno do jeziora Litygajno rzeką Ełk oraz tą samą rzeką od miejscowości Połomka do jeziora Świętajno. Obecnie są tworzone plany kolejnych szlaków, gdyż turystyka kajakowa staje się bardzo popularną formą wypoczynku a szczególne uznanie zdobyła sobie wśród licznie odwiedzających Mazury Niemców.

Najbardziej obiecującą i wciąż rozwijającą się formą wypoczynku jest agroturystyka, która znajduje szczególne uznanie u mieszkańców dużych miast chcących odpocząć od tłumów i zgiełku swoich metropolii a takiego komfortu nie dają im popularne kurorty. Na terenie gminy Świętajno działa Stowarzyszenie Agroturystyczne „Mazurska Kraina” zrzeszające osoby zainteresowanie prowadzeniem tego typu działalności, wśród członków są osoby, które od kilku lat z powodzeniem prowadzą własne gospodarstwa agroturystyczne. Wśród atrakcji jakie oferują takie gospodarstwa są: turystyka konna, rajdy rowerowe, spływy kajakowe, łowienie ryb, biesiady wiejskie, ogniska, wypiek chleba, wyrób masła, degustacja przetworów z mięsa i ryb, udział w pracach polowych i gospodarskich, warsztaty rzeźbiarsko-malarskie oraz muzyki ludowej. Bardzo ważnym atutem takiego sposobu spędzania urlopu jest jego bardzo korzystna cena. Tygodniowy wypoczynek w gospodarstwie w którym mamy zapewniony nocleg, wyżywienie oraz wszystkie atrakcje jest przynajmniej połowę tańszy niż tygodniowy wypoczynek w którymś z polskich kurortów.

Turystyka jest branżą, która bez odpowiedniej reklamy nie może istnieć. Podobnie sytuacja ma się z agroturystyką na terenie gminy Świętajno. Działania promocyjne wymagają ustalonego wcześniej programu, który „(...) powinien zawierać następujące elementy:

- planowane formy i środki reklamy (katalogi, plakaty, ulotki, foldery, reklama prasowa, radiowa, telewizyjna)

- produkcja środków reklamy i możliwości ich dystrybucji,

- kontrola skuteczności reklamy,

- wynikający z celów reklamy budżet.

W programie należy uwzględnić również inne środki promocji jak: sprzedaż osobista, public relations (nawiązywanie stosunków gospodarstwa z otoczeniem), promocja sprzedaży (np. sezonowe obniżki cen). Wzajemne łączenie i uzupełnianie się stosowanych środków promocyjno-reklamowych jest bardzo ważna dla urabiania (kreowania) pożądanego wizerunku (image) gospodarstwa oraz szerszego kierowania publiczną świadomością i potrzebami agroturystycznych klientów."6 Większość w/w form promocji wymaga pomocy „z zewnątrz”, gdyż osoby

6 J.Sikora, Agroturystyczny biznes, s. 74. 
prowadzące gospodarstwa mogą nie posiadać wiedzy niezbędnej do osiągnięcia zamierzonych celów reklamowych. Dla przykładu, zaprojektowanie ulotki reklamowej, z pozoru prostego środka przekazu, wymaga odpowiedniej wiedzy. Nie wystarczy umieścić adresu i numeru telefonu, dzisiejszy klient jest wymagający i chce wiedzieć jaki jest typ gospodarstwa, położenie, okres otwarcia (sezon), ceny (noclegów, wyżywienia, usług), możliwość dojazdu, rezerwacje, kontakt z właścicielem, odległość do najbliższego kąpieliska czy choćby możliwość przyjazdu ze zwierzętami domowymi. Pomocą w tej kwestii służą wyspecjalizowane firmy jednak usługi te wiążą się z kosztami, temu też co raz popularniejsze jest prowadzenie wspólnej akcji reklamowej kilku samodzielnych gospodarstw lub przez regionalną organizacje zrzeszającą właścicieli gospodarstw.

W gminie Świętajno agroturystyka rozwija się bardzo prężnie. Z roku na rok przybywa gospodarstw świadczących usługi agroturystyczne, pensjonatów i hoteli. Trend ten świadczy o rosnącym popycie na tego typu usługi turystyczne. Kilka lat temu niemal $100 \%$ odwiedzających region turystów stanowili Polacy, dziś wypoczywają również obywatele niemal wszystkich krajów Unii oraz dawnego „bloku wschodniego".

Władze samorządowe widząc $w$ agroturystyce szansę na rozwój regionu zleciły przeprowadzenie badań, które wskażą cechy środowiska w poszczególnych częściach gminy mogące stanowić podstawę dla rozwoju turystyki oraz szczególnie cenne przyrodniczo. Warto zwrócić uwagę na fakt, że we wszystkich przedsięwzięciach natura jest traktowana jako wspólne dobro o które trzeba dbać, więc nie może być mowy o rozwoju gminy kosztem środowiska naturalnego. $\mathrm{Z}$ przeprowadzonych badań wynika, że najcenniejsze przyrodniczo są centralna, południowo-wschodnia i północno-wschodnia część gminy.

W centralnej części gminy znajdują się najcenniejsze tereny zarówno pod względem przyrodniczym jak i krajobrazowym co daje możliwość rozwinięcia wszystkich form rekreacji pobytowej pod rygorem przestrzegania zasad ochrony środowiska. Duże, zwarte kompleksy leśne oraz liczne jeziora oraz dogodne połączenie z główną siecią komunikacyjną to dodatkowe atuty przemawiające za zorganizowaną działalnością inwestycyjną.

Północno-wschodni i południowo-wschodni obszar gminy to rozległe tereny rolne sąsiadujące $z$ dużymi kompleksami leśnymi oraz akwenami wodnymi. Tereny te idealnie nadają się do sukcesywnego rozwoju rolnictwa $\mathrm{z}$ jego postępująca restrukturyzacją przy zachowaniu minimalnej ingerencji w środowisko naturalne. Jeziora stwarzają możliwość rozwoju hodowli ryb oraz tworzenia gospodarstw ekologicznych.

Agroturystyka nie jest jedyną formą, która wzbudza zainteresowanie wśród przedstawicieli gminy Świętajno. Szansę na rozwój regionu upatrują oni również w innych formach turystyki. Przeprowadzone badania wskazują, że bardzo dużą przydatność dla rozszerzenia oferty turystycznej gminy stanowią jeziora. 
Dzięki nim możliwe jest zaoferowanie atrakcji turystycznych wodniakom. Aby temu sprostać niezbędne jest stworzenie całej bazy noclegowej w pobliżu jezior oraz przystani wodnych. Amatorzy bardzo aktywnego spędzania czasu powinni mieć do dyspozycji łodzie oraz kajaki, zaś entuzjaści wędkowania spokojne łowiska. Spektrum możliwości wykorzystania walorów przyrodniczych gminy poszerza fakt, iż na rzekach Ełk i Połomka istnieją szlaki kajakowe a w ich pobliżu bardzo atrakcyjne krajobrazy. Na terenie tym są idealne warunki dla stworzenia zielonych szkół dla dzieci i młodzieży oraz rozwoju turystyki pobytowej choćby w oparciu o rewitalizację zespołu dworskiego w Kijach. W centralnej części gminy znajduje się duży kompleks leśny, który może służyć jako doskonałe miejsce dla turystyki przyrodniczej. Dodatkowym atutem jest rozbudowana sieć szlaków rowerowych i pieszych oraz dogodny dojazd, położenie przy drodze GiżyckoOlecko.

\section{Podsumowanie}

W ciągu ostatnich kilku lat znacznie zmienił się obraz polskiej wsi. Rolnik poza umiejętnościami typowo gospodarskimi $w$ wielu wypadkach posiadł wiedzę z marketingu i turystyki. W szczególności dotyczy to obszarów atrakcyjnych turystycznie. Dzięki promocji swojego gospodarstwa, czy tez całej gminy jako obszaru na którym dbałość o środowisko naturalne jest priorytetem, rolnicy uzyskali dodatkowe źródło dochodu a samorządy środki własne, np. na dalszą promocję gminy czy rozwój infrastruktury. Wzrost popularności agroturystyki jest szansą dla biednych regionów Polski o minimalnym stopniu degradacji środowiska naturalnego, na których $w$ wyniku przekształceń polityczno-społecznych w latach 90tych XXw. zostało zlikwidowanych wiele PGR-ów a bezrobocie sięga $40 \%$. Z tej szansy warto skorzystać a gmina Świętajno wie jak to zrobić.

\section{Bibliografia}

Powiat Olecki-Informator, 2000, Olecko.

Studium Uwarunkowań i Kierunków Zagospodarowania Przestrzennego Gminy Świętajno, 2000, BDK, Olsztyn.

LUBIERZYŃSki F.J. , 1970, Ziemia olecka z bliska $i$ z daleka, Bialystok-Olecko.

Sikora J., 1995, Agroturystyczny biznes, Bydgoszcz.

Dемву R., 2000, Olecko. Czasy, ludzie, zdarzenia, Olecko. 